\title{
A MOSAIC DISEASE OF SWEETPOTATO, IPOMOEA BATATA, IN PUERTO RICO
}

A virus causing a mosaic disease of sweetpotato has recently been found in Puerto Rico. The disease is known to occur in different places throughout the Island where sweetpotatoes are grown and is capable of affecting our best commercial varieties. In the field it appears as a distinct mosaic mottling on younger leaves (fig. 1). As the infected plant grows, the leaves become chlorotic and wrinkled. Sometimes these develop puckering in the form of raised green areas alternating with light-green areas. Affected plants are usually stunted. Frequently, however, the above-mentioned symptoms assume a milder manifestation and close scrutiny is necessary to detect infected plants in the field. Laboratory transmission by tuber or cleft grafting usually produces very severe symptoms in susceptible varieties in from 3 weeks to 1 month, consisting of pronounced vein-clearing, chlorosis, wrinkling of leaves, and stunting, followed in many cases by death of the plant.

The virus causing this sweetpotato mosaic is not transmissible by inoculating the juice from infected plants with or without the aid of carborundum, nor by diluting the inoculum with water or a buffer solution. Use of a contaminated knife does not transmit the virus to healthy sweetpotatoes. The only means of transmission so far known is by grafting. Root-grafting of healthy sweetpotato with plugs taken from the root of a diseased plant is the most reliable and rapid method of transmission. Transmission has also been successfully accomplished by cleft-grafting diseased to healthy plants. The plants used in the transmission studies were obtained by cutting single roots of healthy plants and keeping one of the two plants that develop from the pieces as check. So far no insect vector of the virus has been found.

The following sweetpotato varieties were found susceptible when inocu-
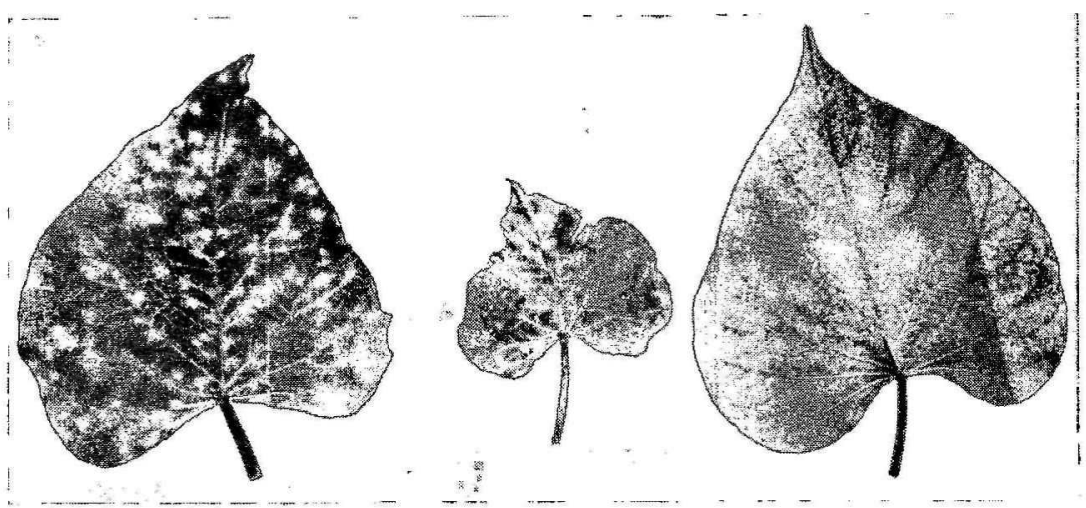

FIG. 1.-Leaves of sweetpotato variety V-10-10 showing symptoms of mosaic; healthy leaf to the right. 
lated by root grafting in the laboratory: U.P.R. 3, U.P.R. 4, L. 240- $\overline{7}$, M.M. 7, V. 10-10, L. 224, L. 138, L. 225, and L. 241. In addition to sweetpotato, (Ipomoea batata), the virus has been transmitted by grafting to I. rubra, a common weed known locally as "bejuco de puerco". The following plants did not show symptoms when inoculated with juice extracted from mosaiced sweetpotatoes: Datura metel, Lycopersicum esculentum, . Vicotiana glutinosa, N. tabacum, Capsicum frutescens, Phaseolus vulgaris, Stizolobium deeringianum, P. lunatus, V'igna unguiculata, Cajan cajan, Ipomoea quinquefolia, I. rubra, and I. purpurea.

Although a mosaic of sweetpotato has been known to be present in Puerto Rico for a number of years, it has not constituted a problem of study until recently. Virus or viruslike diseases of the sweetpotato have been reported in the United States and Africa. These have been reviewed by Doolittle and Harter ${ }^{1}$ and more recently by Webb. ${ }^{2}$ The mosaic dealt with in this note resembles the feathery mottle virus described by Doolittle and Ilarter. Webb has also been able to transmit mechanically a virus which is similar to, if not identical with the feathery mottle of Doolittle and Harter. If this is the case, then our virus differs from feathery mottle in not being transmissible by rubbing, either to sweetpotato nor to $I$. purpurea, which Webb considers to be a good indicator plant for the feathery mottle virus. The only remaining virus which resembles the one under study is that reported by Sheffield ${ }^{3}$ from Africa.

J. Adsuar

Department of Plant Patholog:;

${ }^{1}$ Doolittle, S. P', and Harter, L. L., A graft-transmissible virus of sweetpotato Phytopath. 35 695-704, 1945.

2 Webb, R. E., Some hosts of feathery mottle virus of streetpotato, Plant Di. Rptr. $38448-52,1954$.

${ }^{3}$ Sheffield, F. M. L., Virus diseases of sweetpotato in parts of Africa, Empir: Expt. Abr. 21 184-90, 1953. 